Teosofia: Indonesian Journal of Islamic Mysticism, Vol. 11, No. 1, 2021, pp. 37-58

e-ISSN: 2540-8186; p-ISSN: 2302-8017

DOI: $10.21580 /$ tos.v10i1.8441

\title{
ISLAMIC AUTHORITY FIGURES AND THEIR RELIGIOSCAPES IN INDONESIA
}

\author{
Claudia Seise \\ Berlin Institute of Islamic Theology, Humboldt University Berlin \\ claudia.seise@hu-berlin.de
}

Article history: Received: 20 November 2020; Accepted: 12 February 2021; Published: 26 April 2021

\begin{abstract}
:
In this article I argue that religious authority figures in Indonesia form the core of any given religioscape. A religioscape is a dynamic social space where one religious practice or religious interpretation is predominant. At the same time religious authority figures are influenced by the historically grown religioscape in which they live, and this mutual process affects all the people living in it. With the example of three religious authority figures and their respective learning institutions in Indonesia, I aim to illustrate how Muslim personalities influence and shape the religioscape that surrounds them. The first case study is grounded in the mystic Islam found in Yogyakarta, the second case study explores the mixture of local and Hadhrami influences in the Islamic practice of South Sumatra, while the third case study examines an imported form of reform Islam in a transmigrasi settlement. Of major importance in these case studies will be what influences the religious authority figures and what tools are used to disseminate their thoughts and interpretations of Islam. I argue that the concept of the religioscape enables us to better understand the impact that religious authority figures have on their surroundings and vice versa. It can also serve as a methodological tool to grasp the diverse plurality of Islamic practices in Indonesia.
\end{abstract}

Keywords: Indonesia; Islamic Authorities; Religioscape; Religion; Indonesian Islam

\section{A. Introduction}

I ndonesia is home to the highest Muslim population in the world. Around 200 million Muslims make up $88 \%$ of the country's population. Located between the Indian and the Pacific Ocean, the archipelago has been part of important trading routes for centuries and part of the translocal networks spanning across the Indian Ocean since long before the formation of the modern nation states. ${ }^{1}$ This has resulted in a

1 Ulrike Freitag, "Conclusion: The Diaspora since the Age of Independence," in Hadrami Traders, Scholars, and Statesmen in the Indian Ocean, 1750-1960s, ed. Ulrike Freitag and W.G. Clarence-Smith (Leiden, New York, Köln: Brill, 1997); Ulrike Freitag and Achim von Oppen, Translocality: The Study of Globalising Processes from a Southern Perspective (Leiden, Boston: Brill, 2010). 
vibrant culture that officially accommodates six major religions today, as well as different local belief systems under the umbrella of the national ideology of Pancasila, ${ }^{2}$ the first pillar being the belief in 'the Almighty God' (Ketuhanan yang Maha Esa).

Indonesia is known for its religious pluriformity, and in particular its Islamic pluriformity. This pluriformity has particularly increased since the social reforms (reformasi) that were adopted in 1998. ${ }^{3}$ The diversity of Islamic practices in Indonesia ranges from traditional forms interwoven with pre-Islamic traditions, rituals and beliefs to different types of reformist Islam inspired by the Egyptian reform movement and the Muslim Brotherhood; from fundamental forms of Islam like Salafi Wahhabism that aim to purify Islamic practices to political Islam in various degrees that range from moderate reformist groups to more radical groups calling for a new Islamic caliphate. Additionally, the recent Indonesian decentralization reform has resulted in the implementation of Shari 'a law in Aceh and in Bulukumba, South Sulawesi.

Different scholars have attempted to give a name to this Islamic pluriformity in Indonesia, among them being Geertz, ${ }^{4}$ Woodward,${ }^{5}$ Ridell, ${ }^{6}$ Ali, ${ }^{7}$ and van Bruinessen. ${ }^{8}$ The categories range from santri vs. abangan ${ }^{9}$ to traditionalist vs. modernist, political

2 Pancasila is the official, foundational philosophical theory of Indonesia. The five inseparable and interrelated principles are: 1. Belief in the Almighty God; 2. Just and civilized humanity; 3. The Unity of Indonesia; 4. Democracy guided by the inner wisdom in the unanimity arising out of deliberations among representatives; 5 . Social justice for the whole of the people of Indonesia.

3 Reformasi refers to the Reform Era in Indonesia, which began with the resignation of authoritarian president Suharto on 21 May 1998. Since the fall of the Suharto regime, the country has entered into a period of transition known as the Era Reformasi which is characterized by a more open and liberal sociopolitical environment.

4 Clifford Geertz, The Interpretation of Cultures (Chicago: Chicago University Press, 1973).

5 Mark R. Woodward, Islam in Java: Normative Piety and Mysticism in the Sultanate of Yogyakarta (Arizona: University Arizona Press, 1989); Mark R. Woodward, "Indonesia, Islam, and the Prospect for Democracy," SAIS Review 21, no. 2 (2001): 29-37, https://doi.org/10.1353/sais.2001.0053.

6 Peter G. Riddell, Islam and the Malay-Indonesian World: Transmission and Responses (Honolulu: University of Hawaii Press, 2001).

7 Muhamad Ali, "Categorizing Muslims in Postcolonial Indonesia," Moussons, no. 11 (December 1, 2007): 33-62, https://doi.org/10.4000/moussons.1746.

8 Martin van Bruinessen, "Global and Local in Indonesian Islam," Southeast Asian Studies 37, no. 2 (1999): 158-75; Martin van Bruinessen, "Traditionalist and Islamist Pesantren in Contemporary Indonesia," in The Madrasa in Asia: Political Activism and Transnational Linkages, ed. Farish A. Noor (Amsterdam: Amsterdam University Press, 2008); Martin van Bruinessen, "Modernism and AntiModernism in Indonesian Muslim Responses to Globalisation," in Islam and Development in Southeast Asia: Southeast Asian Muslim Responses to Globalization (Singapore: JICA (Japan International Cooperation Agency) Research Institute, 2009).

9 In The Religion of Java (1960), Geertz put forward the conception of Javanese Islam as being a cultural complex consisting of an abangan substratum onto which Hindu, then Islamic, structures were built. He described three distinct traditions: those of the village abangan (non or little practicing Muslims), the practicing Muslims, whom he called santri, and the prijaji who were the elites and practiced Javanese syncretism. However, these categories are contested. 
vs. cultural Muslim, fundamentalist vs. liberal, great tradition vs. little tradition ${ }^{10}$, and local vs. global Islam. Other categories include normative vs. mystically inclined Islam. Woodward proposed that there exist five basic Islamic orientations: indigenized Islam, traditionalism, modernism, Islamism and neo-modernism. Riddell suggests almost the same categories, namely modernism, traditionalism, radical Islamism, and neomodernism. Neo-modernist Islam — similar to neo-traditionalist Islam — aims to bridge traditionalism and modernism.

However, all these terms are used to capture a lived reality, which in my opinion cannot be essentialized or compartmentalized. Each category seems to at least partially fail to describe the individual nuances of specific Islamic authorities. ${ }^{11}$ The Islamic characteristics the Islamic authorities encounter in the places they live in, are trained in, are influenced by, and eventually transmit to their surrounding. This means that the Islamic thoughts and concepts they have encountered throughout their life and the networks they have formed need to be described in detail in order to obtain a thorough understanding of what each Islamic authority teaches and transmits to the Muslim community. If we wish to better understand what kind of interpretations of Islam and Islamic practices are transmitted to the wider Muslim public by those Islamic authorities, we need to apply thick description, ${ }^{12}$ situational analysis, ${ }^{13}$ and the research methods specific to New Area Studies ${ }^{14}$ while taking an emic perspective. When talking about New Area Studies ${ }^{15}$ it is important to understand that their theory is not based upon a singular discipline from humanities or social sciences but is rather considered to be a cross-disciplinary ${ }^{16}$ or an interdisciplinary endeavor, allowing for 'new' knowledge

10 In Peasant Society and Culture (1956), Redfield proposed specifically local variants or 'little' traditions to occur alongside globally normative 'great 'traditions.

11 In this article, Islamic authorities are Muslims who have been educated in one or more Islamic science and who have a particular audience to transfer Islamic knowledge.

12 Geertz, The Interpretation of Cultures.

13 Adele E. Clarke, Situational Analysis in Practice: Mapping Research with Grounded Theory (Thousand Oaks: SAGE Publishing, 2005).

14 Vincent Houben, "New Area Studies, Translation and Mid Range Concepts," in Area Studies at the Crossroads. Knowledge Production after the Mobility Turn, ed. Katja Mielke and Anna-Katharina Hornige (New York: Palgrave Macmillan, 2017).

15 At the core of New Area Studies theory and methodology lies "the aim of finding relational spatiotemporal outcomes instead of making static, singular and generalized claims of truth. The main subject matter, focusing on processed of world-making within a perspectival time-space constellation called "area", puts human agency and positionality at the centre of the scientific effort". The adoption of a kaleidoscopic dialectic is the principle of generating knowledge with a comparative perspective. (Houben 2020: 56)

16 Peter A. Jackson, "South East Asian Area Studies beyond Anglo-America: Geopolitical Transitions, the Neoliberal Academy and Spatialized Regimes of Knowledge," South East Asia Research 27, no. 1 (January 2, 2019): 49-73, https://doi.org/10.1080/0967828X.2019.1587930. 
to emerge. ${ }^{17}$ Furthermore, it is necessary to master the local language in order to arrive at 'thick knowledge' about one's research field that allows a few from within.

In this article, I argue for a more nuanced approach when analyzing Islamic authority figures in Indonesia. ${ }^{18}$ Here, I have been guided by the principle of New Area Studies to contribute new mid-range concepts based on observations and findings from field research. I suggest that in order to grasp the individual nuances of an Islamic authority, we have to stop compartmentalizing. That does not mean that we should stop using the above mentioned categories altogether; however, I propose that we should only use them as mere road markers, not as final descriptors of what we aim to analyze. In other words we need to go beyond. The concept I have developed in order to grasp the uniqueness and the individual nuances of an Islamic authority in Indonesia is what I refer to as 'religioscapes' based on Appadurai's idea of scapes ${ }^{19}$ and inspired by the concept of translocality as developed by Freitag ${ }^{20}$ and the idea of translocality as used by Mandaville. ${ }^{21}$ I have developed it from different network theories ${ }^{22}$ and fused it with the idea of the metaphor of the rhizome. ${ }^{23}$ Tweed's concept of sacroscape ${ }^{24}$ helped me to consolidate this new concept. Others who contributed to adding or to further refining Appadurai's scapes ${ }^{25}$ have pointed me to the right direction. It was Dobbin's observation

17 Vincent Houben, Ramon Guillermo, and Elísio Macamo, "New Area Studies as an Emerging Discipline. The Way Ahead for Southeast Asian Studies," International Quarterly for Asian Studies 51, no. 3-4 (2020): 51-64, https://doi.org/https://doi.org/10.11588/iqas.2020.3-4.13363.

18 This article is based on qualitative research between 2013 and 2014 in Yogyakarta and South Sumatra and further develops the idea of religioscape which I developed in my dissertation. Claudia Seise, Religioscapes in Muslim Indonesia: Personalities, Institutions and Practices (Berlin: Regiospectra, 2017).

19 Arjun Appadurai, Modernity at Large: Cultural Dimensions of Globalization (Minneapolis, London: University of Minnesota Press, 1996).

20 Freitag and Oppen, Translocality: The Study of Globalising Processes from a Southern Perspective.

21 Peter G. Mandaville, Transnational Muslim Politics: Reimagining the Umma (London: Routledge, 2001).

22 Mark S. Granovetter, "The Strength of Weak Ties," American Journal of Sociology 78, no. 6 (1973): 1360-80; Stephen P. Borgatti and Daniel S. Halgin, "On Network Theory," Organization Science 22, no. 5 (October 2011): 1168-81, https://doi.org/10.1287/orsc.1100.0641; Manuel Castells, The Rise of the Network Society, 2nd ed. (United Kingdom: Wiley-Blackwell, 2010).

23 Julia Verne, Living Translocality: Space, Culture and Economy in Contemporary Swahili Trade (Stuttgart: Franz Steiner Verlag, 2012).

24 Thomas A. Tweed, Crossing and Dwelling: A Theory of Religion (Cambridge, London: Harvard University Press, 2006).

25 Elizabeth McAlister, "Globalization and the Religious Production of Space," Journal for the Scientific Study of Religion 44, no. 3 (September 2005): 249-55, https://doi.org/10.1111/j.14685906.2005.00283.x; R. M. Hayden and T. D. Walker, "Intersecting Religioscapes: A Comparative Approach to Trajectories of Change, Scale, and Competitive Sharing of Religious Spaces," Journal of the American Academy of Religion 81, no. 2 (June 1, 2013): 399-426, https://doi.org/10.1093/jaarel/1ft009. 
of "historical continuity in the stability of religious manifestations and opinions" 26 in the area of West Sumatra, what I had observed, and what was missing in these other concepts. Furthermore, it is my view that the religioscape connected to a religious authority cannot be separated from the place(s) in which the person has lived and studied or has maintained networks to, both real and imaginary. For this purpose, I propose the following definition of religioscape:

Religioscapes are dynamic social spaces where one religious practice and/ or religious interpretation is predominant. Religioscapes are neither purely static nor entirely fluid. Cultivated historically, they include movement, change, and transformation, as well as continuity and stability of religious practices and interpretations. Religioscapes are influenced by individuals and influence individuals. This constitutes a mutual process. Religioscapes can extend and shrink depending on the individuals' preference, influence and connections within it. Different religioscapes can exist within one geographical region and several religioscapes can overlap. Religioscapes allow for an analysis and understanding about relations and dynamics between different spatial scales ranging from the local to the global. ${ }^{27}$

In this sense, religioscapes describe the cultural and social surroundings of an individual — in our context those of a particular Islamic authority — in which culture and social interaction are largely based on religious values. I argue that the concept of religioscapes and their unique character reflect the historically cultivated pluralistic character of Islamic practices in Indonesia and point to an ongoing pluriformity of Islamic interpretations, teachings, and practices in the present day. I further argue that individuals comprise their own unique religioscape. At times these religioscapes can be similar to other religioscapes or overlap with others. However, it is important to understand that each religioscape is unique in its own right - it consists of many individual factors that make up the individual uniqueness of an Islamic authority's religioscape.

Furthermore, I see religioscapes as a framework that allows for an analysis and deeper understanding of how the local, the global, and other spatial scales are connected and the relations that exist between them. The local practices of Islam in Indonesia cannot be analyzed on their own without taking into consideration the dynamics and interactions found in the universally understood global Islam and the discourses connected to it. We also have to consider the local Islamic practices in other parts of the Muslim world. Local Islamic practices as described in this article cannot be essentialized because different networks always connect them to discourses and negotiations within

26 Christine Dobbin, "Islamic Fervour as a Manifestation of Regional Personality in Colonial Indonesia: The Kamang Area, West Sumatra, 1803-1908," Archipel 56, no. 1 (1998): 295-317, https://doi.org/10.3406/arch.1998.3493.

27 Seise, Religioscapes in Muslim Indonesia: Personalities, Institutions and Practices. 
the greater Muslim world. The framework of the religioscape introduces place, space, and scale into the analysis of networks.

In the case of Islam in Indonesia, this means that the framework of the religioscape forms an analytical tool as well as a spatial structure without clear borders (in the sense of Appadurai's use of scape). Using the framework of the religioscape I suggest that connections exist between local practices of Islam encountered in certain places and Islamic practices on different spatial scales. Seen through the lens of the religioscape, local Islamic practices and understandings can be contextualized within the broader discourse of Islam in and outside of Indonesia. I propose that this entanglement of Islam as a global religion with local sets of practices can be opened up through the concept of the religioscape.

\section{B. Plurality of Religioscapes in Indonesia}

Islam as a revealed religion has its roots in the Hejaz, a region in the west of present-day Saudi Arabia. From there it spread to all parts of the Middle East, Central and South Asia, Southeast Asia and the rest of the world. From the very beginning, contact within the umma was maintained and strengthened through the main center, the common qibla and direction of prayer, Mecca as the home of the Ka'ba and destination of the hajj. This contact was also strengthened and maintained through various intellectual centers that were established over time in various places in the Middle East and other regions. Despite being centered on the Hejaz, the Muslim world has always been polycentric and highly interconnected. Although the Hejaz and especially Mecca constitute the ritual center of the Muslim world, different views on Islamic space exist, as exemplified by some of my informants during the course of my research in Indonesia. While some personalities prefer a centered view, others put forward a decentered and more localized view of the Muslim world, especially with regards to the 'knowledge qibla, as I call it. Like the qibla for prayer set in one particular direction - towards the $\mathrm{Ka}$ 'ba in Mecca - I argue that a certain knowledge qibla is directed towards and adjusted to certain places and institutions of learning as a means of safeguarding a certain understanding of Islam.

Religious scholars and traders, often one and the same, established networks across the Muslim world. Focal points in these networks tended to be religious educational institutions, whether informal study circles or formal Islamic schools (madrasa, pesantren). In the colonial and postcolonial era, these networks became denser. With the emergence of modern transport networks, these relations were extended in terms of space and time, thus allowing for more frequent exchange. By the end of the $19^{\text {th }}$ century 
overseas travel, including the hajj to Mecca and "intellectual pilgrimages" 28 to Mecca, Cairo, and other places, was simplified with the extensive use of steam shipping which made the existing ties between the Arabian Peninsula and Southeast Asia much easier. The introduction of air travel further facilitated this exchange for those who could afford it, soon followed by new and faster ways of communication. Today, the extensive use of digital media means that exchange and networking can occur without leaving one's physical place and with comparably very little financial cost. Through email conversation, Facebook and other social media apps, connections between, for example, Indonesian students at Al Azhar University in Egypt and their parents in Indonesia can be almost effortlessly maintained.

Traveling in search of knowledge also referred to as rihla constitutes only one form of travel that can be found within the Muslim religious tradition. Other forms include the aforementioned hajj, visits to local shrines called ziyāra, and hijra, the obligation to migrate from a place where the practice of Islam is constrained to a place where no such constraints exist. ${ }^{29}$ Often, and especially in the case of Indonesia, travel in search of knowledge takes place from the periphery to the center of the Muslim world. Here, Indonesia is commonly considered to be on the periphery of the Muslim world, while places of Islamic learning in the Middle East are thought to be in the center. ${ }^{30}$ For Kyai Abdul Muhaimin, my main informant in the first case study, however, Indonesia is itself a center of Islam and Islamic knowledge, and he opposes "the projection of hierarchical order upon the periphery" ${ }^{31}$. In his view Indonesia is at the center of Islam, especially Java, because his underst anding connects Java and Islam. For Ustad Taufiq Hansuri (died 2019), who is the focus of my second case study, there are many centers of Islam depending on the location of his teachers. According to Ustad Malik in my third case study, the only center of Islam is the Arab speaking world in the Middle East. Locally speaking, the three Islamic authorities introduced in this article and their respective Islamic learning institutions have become centers of Islam in their own right, and others turn to them for knowledge and guidance. In this sense, each of my case studies introduced here represents a unique religioscape.

28 John R. Bowen, "Intellectual Pilgrimages and Local Norms in Fashioning Indonesian Islam," Revue Des Mondes Musulmans et de La Méditerranée, no. 123 (July 4, 2008): 37-54, https://doi.org/10.4000/remmm.5323.

29 Dale F. Eickelman and James Piscatori, "Social Theory in the Study of Muslim Societies," in Muslim Travellers: Pilgrimage, Migration and the Religious Imagination, ed. Dale F. Eickelman and James Piscatori (Berkeley, Los Angeles: The University of California Press, 1990).

30 Michael R. Feener, "South-East Asian Localisations of Islam and Participation within a Global Umma, c. 1500-1800," in The New Cambridge History of Islam, ed. David O. Morgan and Aanthony Reid (Cambridge, London: Cambridge University Press, 2010); Christopher M. Joll, "Local and Global Islams in Southeast Asia: Historical and Anthropological Perspectives," in Social Science and Knowledge in a Globalising World, ed. Z. Ibrahim (Petaling Jaya: PSSM/SIRDC, 2012); Eickelman and Piscatori, "Social Theory in the Study of Muslim Societies."

31 Eickelman and Piscatori, "Social Theory in the Study of Muslim Societies." 
Historically, Indonesian Islamic authorities have forged and maintained relations with various institutions and individuals on the local and translocal level. However, Azra $^{32}$ argues that by the 16th century there were religious teachers of Malay origin in Mecca who taught new students arriving from the Indies. ${ }^{33}$ Besides the movement from the Indies, the movement toward the Malay world was favored not only by returnees from hajj and students in the Middle East, but also by individuals - mostly traders with a $d a^{6}$ wa mission - originally from the area of Hadhramaut in Yemen. ${ }^{34}$ These multidirectional and multi-level movements and exchanges between Islamic institutions and individuals in Indonesia and "intellectual centers for the study of Islam" 35 were maintained and expanded on all levels and in all directions, thus shaping the religioscape of Islamic authorities in contemporary Indonesia. New centers for the study of Islam have emerged besides the historically renowned ones in contemporary Saudi Arabia, Yemen and Egypt. One of these new centers is North America. Since the 1970s, Indonesian post-graduate students began enrolling in religious studies at McGill and the University of Chicago. ${ }^{36}$ Nevertheless, it is my opinion that the dichotomy between the Indonesian periphery and the center(s) of Islam located in the Middle East is still upheld most of the time.

The three Islamic authorities and their respective learning institutions analyzed here maintain different connections on the local, national, and translocal level and are connected to various religious networks. They are receivers as well as transmitters of Islamic knowledge and practice. Translocal here refers to translocality, which describes "the sum of phenomena which result from a multitude of circulations and transfer" and "the outcome of concrete movements of people, goods, ideas and symbols which span spatial distances and cross boundaries, be they geographical, cultural or political." 37 This process can be observed in all three case studies introduced here. In contrast to the concept of transnationalism, translocality does not "presuppose the existence of nationstates [and does not] privilege the perspective of national elites." 38 This is important when considering the development of Indonesian Islam, its Islamic authorities, and their religious education institutions because ties with different areas in the Middle East and

32 Azyumardi Azra, The Origins of Islamic Reformism in Southeast Asia. Networks of Malay-Indonesian and Middle Eastern 'Ulama' in the Seventeenth and Eighteenth Centuries, Southeast Asia Publications Series (Honolulu: University of Hawaii Press, 2004).

33 Bowen, "Intellectual Pilgrimages and Local Norms in Fashioning Indonesian Islam."

34 Peter G. Riddell, "Religious Links between Hadhramaut and the Malay-Indonesian World, C. 1850 to C. 1950," in Hadrami Traders, Scholars, and Statesmen in the Indian Ocean, 1750-1960s, ed. Ulrike Freitag and W.G. Clarence-Smith (Leiden, New York, Köln: Brill, 1997), 217-30; Freitag, "Conclusion: The Diaspora since the Age of Independence."

35 Bowen, "Intellectual Pilgrimages and Local Norms in Fashioning Indonesian Islam."

36 Bowen.

37 Freitag and Oppen, Translocality: The Study of Globalising Processes from a Southern Perspective.

38 Freitag and Oppen. 
outside the Middle East were forged prior to the founding of the Indonesian nation state in 1945. Secondly, the approach of transnationalism in the study of Indonesian Islam, its scholars and pesantren, would exclude the relations that are maintained with institutions and individuals or communities on the local and national level. It is especially the connections on the local level that allow us to understand how common Muslims come to their understanding of Islam and Islamic practices through Islamic authorities. The three Islamic authorities and their respective learning institutions in this article are located in distinct geographical, social, and cultural places that influence the individual and the learning institution and are in turn influenced by the latter.

I will illustrate the importance of applying the concept of the religioscapes to the three Islamic authorities from my case studies. The examples will show that in order to obtain a better understanding of Islamic authorities, their thoughts and interpretations of Islam, and Islamic practices, it is necessary to apply a holistic concept and methodological tool: the religioscape.

\section{Islam is Java and Java is Islam}

Kyai Muhaimin is the leader of the Pondok Pesantren Nurul Ummahat in Kota Gede, Yogyakarta. He is a $k_{y a i^{39}}$, father of eight, preacher, lecturer, Pancasila activist, member and co-founder of the interreligious dialogue forum in Yogyakarta, Nahdlatul Ulama (NU) sympathizer, lover of Javanese culture, ex-politician, trainer for gender awareness, alumni of the Krapyak pesantren, and NGO activist. He can be described as a Wahhabi opponent, tasawwuf practitioner, bicycle rider, imām, advocate of Indonesian Islam, traveller, former head of the Indonesia Conference on Religion and Peace, visitor to sacred places and graves, and critic of an Arabic, transnational Islam. If we would want to apply compartmentalizing categories, he can be described as a traditionalist, modernist, liberal, fundamentalist, moderate, pluralist, ${ }^{40}$ cultural and political Muslim who practices both local and global Islam, normative and mystical forms of Islam, and is a santri ${ }^{11}$, an abangan, and much more. The possible application of all these categories illustrates that to understand Kyai Abdul Muhaimin's thoughts and interpretations of Islam, we need to look beyond these labels. This would entail analyzing the details and unique features that make up the immediate religioscape he is part of, by which he is influenced, and which he in turn influences. We need to understand his individual religioscape. Only then can we obtain an idea of what he - as

39 Muslim scholar that is usually the founder of a pesantren; this is not a normative Islamic term but a term that emerged in Indonesian, especially Javanese society.

40 Mohamad Sobirin, "Kiai Muhaimin and His Outreach Activity of Dakwah for Promoting Moderation and Preventing Conflict: Seeding Pluralism Vis-a-Vis Preaching Religion," RELIGIA 21, no. 2 (2018): 125-40, https://doi.org/10.28918/religia.v21i2.1505.

41 Santri here does not refer to a student at a pesantren but refers to the category opposite to abangan; contested categories coined by Geertz (1960). See footnote number nine above. 
an Islamic authority - transmits to his followers, his santri (student at a pesantren) and the segment of the general public that is within his reach.

Kyai Abdul Muhaimin and his Pesantren Nurul Ummahat in Kota Gede, Yogyakarta reflect what is commonly referred to as the 'traditional' form of Islamic practice in Yogyakarta, which includes traditional rituals and what I describe as Javanese Islamic symbolism. Traditional religious tolerance and pluralism in Yogyakarta is one reason for the presence of interreligious dialogue networks in which he participates. The case study of Kyai Abdul Muhaimin, his networks and interpretation and practice of Islam, reflect one kind of religioscape in Yogyakarta where the localization of Islamic practices includes pluralist and interreligious harmony. I argue that the case study of Kyai Abdul Muhaimin represents a continuation of the "mystic synthesis" in Java, ${ }^{42}$ and Kyai Abdul Muhaimin can be seen to embody a historical phenomenon - the fusion of Javanese and Muslim identity that was commenced under Sultan Agung. This fact links back to the part of historical continuity and stability I have included in my definition of religioscape. Kyai Abdul Muhaimin's outlook also reflects an embrace of openness towards new ideas and the urge to preserve harmony, which is an important concept in Javanese culture. Here we can see that the place needs to be considered and understood as an influential factor for the individual Muslim and his religioscape.

Kyai Abdul Muhaimin is an interesting example of what it means to be an Indonesian Javanese Muslim: Islam and Java (Javanese culture) are the same ("Islam adalah Java dan Java adalah Islam'). This statement of his is reminiscent of Woodward who argued that Islam is the predominant force of religious beliefs and rituals of people in Yogyakarta, Central Java. ${ }^{43}$ Kyai Abdul Muhaimin stands as a unique example that combines, reflects on and critiques several major discourses within the contemporary Indonesian Muslim community while holding firm to his Javanese Muslim identity. It is his pesantren and various Islamic forums, study circles and gatherings where his interpretations, teachings and thoughts are transferred to the wider Muslim community.

One of Kyai Abdul Muhaimin's central arguments that he spreads in his religioscape is that Islam is universal. However, his understanding of 'universal' is different to what other Muslim groups come to understand of it, namely that it has to be the same all over the world. According to him, the statement that Islam is universal means that Islam must be able to "be adapted, to acculturate, to coexist with and accommodate local culture and local wisdom." Today, he explains, there are some Muslims in Indonesia who try to reduce Islam to Arabism and view local culture and tradition as something alien that pollutes the original and authentic Islam. He sees his

42 M.C. Ricklefs, Mystic Synthesis in Java: A History of Islamization from the Fourteenth to the Early Nine-Teenth Centuries (Novalk: East Bridge, 2006).

43 Woodward, Islam in Java: Normative Piety and Mysticism in the Sultanate of Yogyakarta. 
task as teaching the different Muslim communities in Yogyakarta that the traditionally cultivated and established way of Islamic practices in Yogyakarta is not wrong, as claimed by some minority Muslim groups. He argues that the symbolic way through which the Walisongo ${ }^{44}$ spread Islam in Java can still be applied today because this symbolism helps the majority of the common Javanese people to understand, comprehend and implement Islamic teachings in their daily lives. One characteristic of Kyai Abdul Muhaimin's thought is the combination of his Javanese cultural heritage with his understanding and interpretation of Islam. He stresses the importance of not losing the knowledge of how Javanese traditional clothes, food and celebrations receive an Islamic meaning through the interpretation of a multi-dimensional understanding of the Islamic legacy in Java.

One part of the religioscape of Islamic authorities is their educational background and personalities which inspired them. For example, Kyai Abdul Muhaimin has been highly influenced by former Indonesian president and Islamic authority Gus Dur (Abdurrahman Wahid, 1940-2009), especially in his passion for interreligious dialogue. In addition, his love for the Pancasila was fueled by his teacher Mbah Lim (Kyai Haji Muslim Rifa'i Imam Puro), the founder of the Pesantren Al-Mutaqqin Pancasila Sakti. Furthermore, his connection with the Krapyak Pesantren and his teacher Kyai Ali Maksum has played an important role in Kyai Abdul Muhaimin's understanding and practice of Islam.

Besides these Islamic authorities, Kyai Abdul Muhaimin's passion for his own local culture and tradition, as explained above, features heavily in how he understands and practices Islam. In this sense, the unique religioscape that surrounds him has been cultivated historically. We can observe some form of continuity and stability in the area of Yogyakarta in the way Islam and Javanese culture have been fused. This fusion is carried on by Kyai Abdul Muhaimin in his unique individual religioscape. However, at the same time, religioscapes include movement, change, and transformation, as I have described in my definition of religioscapes earlier. This too can be observed from the above example. The notion of tolerance is already anchored in the place of Yogyakarta. However, Kyai Abdul Muhaimin practices tolerance in his own unique way by actively engaging in interreligious dialogue on various spatial scales, thereby expanding his locally influenced religioscape with a strong focus on interreligious tolerance on the national and global level. By traveling to other parts of the world and inviting international guests to his pesantren, Kyai Abdul Muhaimin passes on his understanding of tolerance and Islam to individuals on different spatial scales. In this sense, he has been influenced by the religioscape he is living in while influencing and transforming this very same religioscape to establish his own unique religioscape.

44 Among traditional Indonesian Muslims, the Walisongo are believed to have contributed a significant part to spreading Islam in Java between the 14th and 17 th centuries. 


\section{Keeping with Tradition}

Ustad Taufiq Hasnuri ${ }^{45}$ and his cawisan (local Palembang dialect for religious classes) activities reflect two traditional, often similar and mutually related forms of Islamic practices in the bigger religioscape of Palembang, South Sumatra. The first of these practices is described by Azra $^{46}$ as shari ${ }^{\prime}$ a based neo-Sufism. The second is connected to the Islamic practices found amongst the descendants of immigrants from Hadhramaut (Yemen). Ustad Taufiq Hasnuri's understanding and practice of Islam can be understood as a continuation of these two forms of Islamic practices which are still found in Palembang today. Both of these Islamic interpretations and practices were once supported by the Sultans of Palembang, especially in the 18th and 19th centuries, and therefore reflect a historical continuity and stability in the religioscapes of Palembang. Due to the strong presence of these two shari $a$ and tasawwuf based Islamic practices, syncretic practices that can still be found in Java are rarely found in Palembang. On the other hand, modern reformist movements like the Muhammadiyah, the Muslim Brotherhood or the Salafists that are relatively influential in Java only represent a small minority in this part of Indonesia. This second case study illustrates how local Islamic practices are connected to and influenced by Islamic practices from other parts of the Muslim world (present and past) and how an analysis and understanding of relations and dynamics between different spatial scales ranging from the local to the global can be obtained through considering the broader religioscape.

Ustad Taufiq's Islamic educational background was characterized by the traditional Shāfi'i madh'hab, which is adhered to by most of the Habaib (descendants of the Prophet Muhammad) in Palembang and constitutes an identity marker for this group and their sympathizers. Besides the adoption of Shāfíi fiqh, different Islamic rituals and practices are adopted from the tradition of the Hadhrami descendants in Palembang and incorporated into everyday life. One example is the celebration of the Maulid, the Prophet's birthday, which has been intensified and extended in Palembang, consisting of festivities over forty days. Another important ritual introduced by the Habaib community in Palembang is the ziarah kubro ${ }^{47}$. During his lifetime Ustad Taufiq Hasnuri regularly participated in both rituals and was part of the organizing committees, thereby taking an active role in the promotion and spreading of Hadhrami rituals and identity in the religioscape of Palembang.

45 Ustad Taufiq Hasnuri suddenly passed away in November 2019 during one of my follow-up research stays. His cawisan activities are now carried on by his eldest son and supported by senior Muslim scholars in Palembang.

46 Azra, The Origins of Islamic Reformism in Southeast Asia. Networks of Malay-Indonesian and Middle Eastern 'Ulama' in the Seventeenth and Eighteenth Centuries.

47 A major ziarah event in the South Sumatran city of Palembang where graves of famous scholars and royalty are visited by thousands of people. In recent years it has become a translocal event where Habaib and their sympathizers from other parts of the world come to Palembang to take part. 
Furthermore, Ustad Taufiq adhered to the traditional model of acquiring and transferring Islamic knowledge in Palembang. This consists of sitting through a religious lecture called cawisan, led by a teacher or ulama. At these cawisan, texts from classical scholarship (kitab) were read and explained. Ustad Taufiq regularly held several such cawisan a week in his home. These cawisan usually targeted different audiences such as middle-aged men and women, and youth, both male and female.

Besides Ustad Taufiq being influenced by the surrounding religioscape, he also took an active part in shaping the same. His love and veneration for the ulama inspired him to decorate his teaching hall in a unique way. Opposite his customary seating place, Ustad Taufiq had arranged portraits of well-known local ulama from Palembang with which he was directly connected through a chain of obtaining knowledge (sanad). Above his seating place hung the picture of Shaykh Habib Umar bin Hafiz (born 1963) from Yemen, founder of the well-known madrasa Darul Mustafa in Tarim, and Shaykh Muhammad Alawi Al-Maliki (1944-2004), a traditional, non-Wahhabi scholar from Mecca. Both ulama have had many students from Indonesia. Many more pictures of well-known ulama circled the upper part of his teaching hall. Interestingly, many people in Palembang followed him in displaying the photographs of their favorite ulamain their homes. This illustrates how Ustad Taufiq was not only influenced by the religioscape that surrounded him, but he actively shaped it. Especially through his cawisan that catered mainly to non-Habaib people, he formed his own unique religioscape within the greater religioscape that surrounded him.

The case study of Ustad Taufiq, his cawisan and the Habaib community represent what I have termed as the established and historically cultivated traditional form of Islamic practices in Palembang. Central to understanding Ustad Taufiq's Islamic understanding and practices are his educational as well as spiritual connections with ulama that belong to the majority of Sunni Islam, the Ahl al-Sunna wa'l-Jama' a. ${ }^{48}$ When he taught their books to the general public, he aimed to keep this form of Islamic interpretation alive. In this way, he contributed to the continuation of established and historically cultivated forms of Islamic practices within the religioscape of Palembang.

Besides Ustad Taufiq's unique contribution to the historically cultivated religioscape of Palembang in the form of displaying photographs of inspirational ulama, he aimed to shape his evolving religioscape yet in another way. All books read and explained by Ustad Taufiq during his cawisan were written in Malay in Jawi script (with Arabic letters). He explained that he was the only one in Palembang who taught the

48 'Adherents to the Tradition of the Prophet and the Community' is an essential term in the broader Islamic discourse and serves as a mode of identification with the (supposedly) correct way of practicing Islam. It is a contested term because it seems often to be used to legitimize and strengthen a certain mode of practicing Islam. Furthermore, within the inner Islamic debates in Indonesia, competing definitions exist. 
Penawar (Bagi) Hati' ${ }^{49}$ and other Malay works written in Jawi script. One has to find one's place among the different ulama, he explained. This statement suggests that, similar to other scapes, the religioscape of Palembang is contested by various actors. ${ }^{50}$ As in a marketplace, a religious authority has to offer something unique in order to attract followers. In the case of Ustad Taufiq, this Alleinstellungsmerkmal was the reading of the Malay kitab kuning written in Jawi script which cannot be bought in Indonesia, but have to be imported from Malaysia. Reading these works set Ustad Taufiq's religioscape apart from the religioscape that influenced him in his surroundings. It also illustrates that different religioscapes can exist within one geographical area and can overlap.

\section{E. The "true" Islam}

Ustad Malik is the head of the Pesantren As-Salam in South Sumatra. He is a former PK (Partai Keadilan or Justice Party) activist, preacher, alumni from Saudi Arabia, father of 11 children, co-founder of several other pesantren, Gontor alumni and critic, imām, critic of ziarah, teacher, fierce opponent of any mystical Islamic practices, kyai, self-proclaimed reformist, mosque builder, follower of Muhammad Ibn Abd alWahhab (1703-92) and Sayyid Qutb (1906-66). He is originally from East Java, which is traditionally a stronghold of the Nahdlatul Ulama (NU) and a critic of the PKS (Partai Keadilan Sejaterah or Prosperous Justice Party; successor of the PK) and an advocate for a universal unitary Islam based solely on the Qur'an and Sunnah.

Ustad Malik stands as an example of an Indonesian Muslim who opposes all forms of local or mystical Islamic practices. He is a fierce critic of many practices found among NU followers, such as selamatan (communal feast held on various religious occasions and lifecycle ceremonies), HAUL (remembrance of the death of an Islamic scholar or shaykh), maulid (birthday of the Prophet Muhammad) celebrations, extensive dzikir practices, amulets, and any supposedly supernatural beliefs that go against his understanding of tauhid (the Oneness of Allah). Using the proposed categories mentioned in the beginning of this paper, he can be described as a modernist, fundamentalist, and political Muslim who practices and teaches a normative form of Islam within an area that is mostly influenced by what he refers to as bid'ah (deviated) practices tolerated or exercised by NU sympathizers or followers.

49 Written by 'Abd al-Qadir ibn Abd al-Muttalib al-Indunisi al-Mandili. This is a kitab known and used in Malaysia rather than in Indonesia. Contrary to most kitab kuning found in Indonesia that are written in Arabic, Penawar (Bagi) Hati is written in Malay with Jawi script. It was completed in Mecca in 1958 and reprinted in Thailand in 1964. Nicholas Heer, "A Concise Handlist of Jawi Authors and Their Works," NELC Faculty Papers (Seattle, Washington: University of Washington, 2012), https://digital.lib.washington.edu/researchworks/handle/1773/4870. accessed June 2021.

50 Appadurai, Modernity at Large: Cultural Dimensions of Globalization. 
Like Kyai Abdul Muhaimin in my first case study, Ustad Malik utilizes his pesantren to transfer his understanding, interpretation and practice of Islam to his santri or through his lectures to the wider Muslim community. However, unlike Kyai Abdul Muhaimin, Ustad Malik selects the best of his santri to be sent abroad to the Middle East for a university education and employs them as teaching staff in his pesantren upon their return. This form of caderization ensures that the original vision and mission of the pesantren and the Islamic understanding of its founders, including those of Ustad Malik, are maintained. Ustad Malik is a sympathizer of what he calls the "true spirit" of the Pancasila, which in his opinion is tauhid.

Ustad Malik is originally from East Java and has studied at the well-known modern pesantren Gontor in Ponorogo, East Java. ${ }^{51}$ After his pesantren education, Ustad Malik was asked to teach at a pesantren in Lampung before being granted a scholarship to study in Riyadh, Saudi Arabia. In addition to the educational connections, Ustad Malik maintains other connections with the Middle East, mostly in the form of financial sponsorship.

The area surrounding the Pesantren As-Salam is rural. Rubber and oil palm plantations are plentiful in this major transmigrasi area. ${ }^{52}$ Although situated in South Sumatra where the majority of the population is ethnically Malay, most people living in the surrounding area in the village Sri Gunung are of Javanese origin and are usually referred to as pendatang (lit.: new people), or more rudely as wong $\operatorname{tran}(s)$ (transmigration people). This latter term references their special status in taking part in a government sponsored resettlement program where they were resettled in rural areas that used to be jungle and wilderness. An important feature of the religious background of a majority of these transmigrasi families is that they have an NU background in the sense that they follow some of the prevalent accepted Islamic practices and rituals. Nevertheless, in my opinion it is important to note that there does not exist an established and cultivated religious or cultural tradition in the area of Sri Gunung. The fixed traditional entity of the Javanese kampung (village) and its rather restrictive character which prioritizes the interest of the kampung community over that of the individual has been mostly left behind. Like other transmigrasi areas, ${ }^{53}$ individual success is a primary motivator in the region of Sri Gunung. I see the lack of a cultivated religious tradition in this area as a major factor for the success of the transmission of Ustad Malik's interpretation of Islamic practices and the implementation of a new religioscape in this area. This relatively new religioscape is shaped by the historically

51 Pondok Modern Darussalam Gontor, founded in 1926.

52 Area of new settlement resulting from a government program for resettlement.

53 See Andreas Heigl and Joachim Schwarz, "Transmigration - Eine Mobilitätsstudie in Einer Herkunftsregion," ERDKUNDE 54, no. 3 (2000): https://doi.org/10.3112/erdkunde.2000.03.06. 
cultivated religious practice of an area on a different spatial scale, which is mostly Saudi Arabian Wahhabism.

However, besides these major influences from a global Islamic scale, Ustad Malik has created his own unique religioscape. The following statement of his illustrates what is especially important to him and what is transferred to his students, followers, and the surrounding community:

I see myself as a small pellet from the umma of the Prophet Muhammad who wants to return to the Sunnah. That's all. A pellet of dust. There is not much we can do. A pellet of dust that seeks to return to asala, the genuine way of being religious. [...] [T]he umma of the Prophet Muhammad is divided into 73 groups, more than the divisions of the Jews and Christians. All of them go to hell except for one group. Which group is hard to determine. Each group claims to be superior. All groups claim that they are the good ones, that they are reformist. [So, this is why it is best] not to be fanatic about any one group. If you are fanatic about one group, you become excessive, and when you become excessive you become proud [Ind.: ujub]. Once you are proud, you break away from the Qur'an. You become shaytan [satan]. That is why I take the principle: as long as it is true [Ind.: benar] we are together, but if it is bathil [false], sorry, I cannot [be together]. [...] That is why the balance [of our emphasis] is [on the] Qur'an and Sunnah. If it is appropriate [Ind.: cocok] to the Sunnah, we take it. If not, we leave it.

Ustad Malik's statement above includes most of the major points in his understanding of Islam. First of all, he sees himself as belonging to the umma of the Prophet Muhammad and aims to return to the Prophet's true teachings and practices (Sunnah) and the genuine way of being religious (kemurnian dalam beragama), which he terms asala (Ind.: ashola). Only through the Sunnah of the Prophet Muhammad can one return to asala - the genuine way of being religious. His understanding of "the genuine way of being religious" refers to the genuine way of practicing Islam. What I translated as "genuine way" includes many more connotations. The noun kemurnian derives from the adjective murni, which not only translates as pure, pristine, unspoiled, unvarnished, and genuine, but also as neat, precious, neutral, untainted, unadulterated and whole. Murni is colloquially used in connection with ideas, ideals, thoughts and truth, but also when speaking about precious metals and chastity. When speaking about or connecting it to religion and Islam, all of these meanings resonate. Kemurnian translates as purity, genuineness, refinement, clarity, and also as chastity and honor. To speak of "kemurnian dalam beragama" implies that there must be a false (not genuine), spoilt, tainted way to be religious. It also implies that religious (Islamic) practices can be purified (dimurnikan). It is this purification (pemurnian) that features heavily in Ustad Malik's role as $d a{ }^{\prime}{ }^{54}$ and teacher, and in his interaction with local communities. I propose that the key element of his religioscape is purification of the religioscapes that surround him.

54 A da' $i$ is generally a person that engages in $d a^{\prime} w a h$, the act of inviting people to Islam. 
Ustad Malik is not only active in the communities close to the pesantren AsSalam, but regularly travels to Palembang and other places to deliver lectures and maintain silaturahm ${ }^{55}$ relations. One regular study circle to which Ustad Malik speaks about Islam takes place in a mosque at a perumahan, a housing complex similar to a gated community in Palembang. According to my observations, this housing complex also represents a place where no original traditional culture exists. People who live there come from all over Indonesia and have lived their lives outside of places with a traditional, historically cultivated practice of Islam. In this respect, this particular housing complex in Palembang is similar to the transmigrasi area of Sri Gunung.

My findings show that the case study of Ustad Malik and his pesantren stands as an example of a global, non-localized form of Islamic practice and interpretation that is closely connected to the Salafi school of thought, which is found both in the teachings of the Muslim Brotherhood as well as in the teachings of Saudi Arabian Wahhabism. When Ustad Malik refers to himself as a reformist, he does not only refer to his connection and identification with reformist Islam which originated in the Middle East; he identifies directly with the Hadith which states that in every age there should be a group that is reformist (mujaddid) and returns Islam to its original sources, the Qur'an and the Sunnah. Here, Ustad Malik's argument affirms the general observation that "religious reform has occurred in the Islamic world regularly," 56 and Indonesia is no exception. As the analysis above demonstrates, Ustad Malik and the Pesantren AsSalam represent part of a contemporary movement that aims to reform and 'purify' Islam in Indonesia.

However, I argue that this contemporary wave of reform can be observed especially in places that do not have a historically cultivated and established culture of religious practices, i.e. a religioscape. Among these places are transmigrasi areas in rural regions and gated communities, perumahaan, in urban areas. In these places, Islamic authorities like Ustad Malik construct their religioscape that is detached from locally cultivated interpretations of Islamic practices. Rather, these individual religioscapes are grounded in places on different spatial scales. Using qualitative education as a tool, Ustad Malik is successful in attracting young people from the transmigrasi area to the pesantren where he shapes their understanding and practice of Islam. The school's

55 The concept of silaturahmi is found everywhere among the Indonesian Muslim community. Visiting a friend, family members or a teacher is often referred to as silaturahmi, not as berkunjung (visit). Silaturahmi consists of two levels: it is both a practice and an intention (Ind:: niat). It applies to the persons who visit as well the persons who receive the visiting party. For a further discussion on silaturahmi see Claudia Seise, "The Transformational Power of Barokah and Silaturahmi in Muslim Indonesia," International Journal of Islam in Asia 1 (March 26, 2021): 1-20, https://doi.org/10.1163/25899996-01020001.

56 Vincent Houben, "Islam and the Perception of Islam in Contemporary Indonesia," Heidelberg Ethnology, Occasional Paper, no. $\quad 3 \quad$ (2015): https://doi.org/https://doi.org/10.11588/hdethn.0.0.25362. 
authority figures aim to eradicate and purify local Islamic practices and rituals by guiding the young generation away from such practices and toward the 'correct' way of practicing Islam. This aim transcends the pesantren's boundaries and also targets the surrounding areas towards a general 'piousization' of the transmigrasi area. The primary tools for transforming the religioscape of Sri Gunung, besides the pesantren, are the building of mosques with the help of sponsorship from Saudi Arabia, and the opening of two representational jilbab $b^{57}$ stores.

\section{F. Conclusion}

I have proposed that the analysis of a specific religioscape and its actors can be seen as an extended form of network analysis and a legitimate way to understand Islamic authorities in Indonesia beyond the commonly applied categories of traditional/ modern/ fundamental/ extremist Islam. However, it is also more than that. The religioscape connects the local perspective of place with different spatial scales. Religioscape is the connecting element between local and global and it allows for the illustration of the relations that exist between local and global. The framework of the religioscape introduces place, space, and scale into the analysis of the networks of Islamic authorities. In the case of Islam in Indonesia this means that the framework of the religioscape forms an analytical tool as well as a spatial structure without clearly defined borders. I propose that through the framework of the religioscape the connection between local practices of Islam and Islamic practices on different spatial scales can be given additional weight. Furthermore, through the lens of the religioscape it is possible to contextualize local Islamic practices and understandings within the broader discourse of Islam in and outside of Indonesia. Therefore, using religioscape as a framework can help to avoid the essentialization of certain Islamic practices and understandings adhered to by Islamic authorities. By analyzing the religioscape of Islamic authorities we are able to understand what they transmit to their community and how the public understanding of Islam and Islamic practices are formed and influenced.

Furthermore, I have argued that religioscapes and their unique character within the various areas of Indonesia reflect the historically cultivated plural character of Islamic practices in the country and point to an ongoing pluriformity of Islamic interpretations, teachings, and practices in the present day. The three religioscapes that emerge from my case studies represent part of this pluriformity, yet without representing all of it. It is my opinion that each and every Islamic authority in Indonesia is able to form his or her own unique religioscape. Perspective is an additional feature of a religioscape that merits further analysis to.

Moreover, I have not touched upon the presence of the Indonesian nation state within Indonesia's religioscapes in this article. However, from my research findings, I

57 In Indonesia jilbab refers to the typical Indonesian Muslim headcovering, i.e. headscarf. 
can conclude that it can be observed that although the nation state is not completely absent within a respective religioscape, it does not shape a religioscape in any meaningful way. However, at times interfaces emerge between the Islamic interpretation and practice predominant in one religioscape and the general discourse followed by the Indonesian nation state concerning the interpretation of Islam. This can be seen in the example of Kyai Abdul Muhaimin. His idea of a 'cultural Islam' which is moderate and plural and common to the religioscape of Yogyakarta is also reflected in the national discourse about the uniqueness of Indonesian Islam which is supposedly tolerant, moderate and peaceful.

For the future study of Islam in Indonesia, this means that a vast field is still open for research. Studies on Islamic authorities or Muslim personalities, their networks, and their connections to the place in which they live, will enable us to arrive at a more detailed understanding of the dynamics at work. The focus on the individual, rather than on Islamic groups or organizations, allows us to understand how Islamic interpretations and practices are spread at the micro level. The focus on the personality's educational background, connections and networks, both real-life connections as well as inspirational and imaginary ones, help us to contextualize our observations. As a midrange concept, the religioscape also has the potential to be applied to studying religious authorities in other regions of the world. 


\section{Bibliography}

Ali, Muhamad. "Categorizing Muslims in Postcolonial Indonesia." Moussons, no. 11 (December 1, 2007): 33-62. https://doi.org/10.4000/moussons.1746.

Appadurai, Arjun. Modernity at Large: Cultural Dimensions of Globalization. Minneapolis, London: University of Minnesota Press, 1996.

Azra, Azyumardi. The Origins of Islamic Reformism in Southeast Asia. Networks of Malay-Indonesian and Middle Eastern 'Ulama's in the Seventeenth and Eighteenth Centuries. Southeast Asia Publications Series. Honolulu: University of Hawaii Press, 2004.

Borgatti, Stephen P., and Daniel S. Halgin. "On Network Theory.” Organization Science 22, no. 5 (October 2011): 1168-81. https://doi.org/10.1287/orsc.1100.0641.

Bowen, John R. "Intellectual Pilgrimages and Local Norms in Fashioning Indonesian Islam." Revue Des Mondes Musulmans et de La Méditerranée, no. 123 (July 4, 2008): 37-54. https://doi.org/10.4000/remmm.5323.

Bruinessen, Martin van. "Global and Local in Indonesian Islam." Southeast Asian Studies 37, no. 2 (1999): 158-75.

- "Modernism and Anti-Modernism in Indonesian Muslim Responses to Globalisation." In Islam and Development in Southeast Asia: Southeast Asian Muslim Responses to Globalization. Singapore: JICA (Japan International Cooperation Agency) Research Institute, 2009.

. "Traditionalist and Islamist Pesantren in Contemporary Indonesia." In The Madrasa in Asia: Political Activism and Transnational Linkages, edited by Farish A. Noor. Amsterdam: Amsterdam University Press, 2008.

Castells, Manuel. The Rise of the Network Society. 2nd ed. United Kingdom: WileyBlackwell, 2010.

Clarke, Adele E. Situational Analysis in Practice: Mapping Research with Grounded Theory. Thousand Oaks: SAGE Publishing, 2005.

Dobbin, Christine. "Islamic Fervour as a Manifestation of Regional Personality in Colonial Indonesia: The Kamang Area, West Sumatra, 1803-1908." Archipel 56, no. 1 (1998): 295-317. https://doi.org/10.3406/arch.1998.3493.

Eickelman, Dale F., and James Piscatori. "Social Theory in the Study of Muslim Societies." In Muslim Travellers: Pilgrimage, Migration and the Religious Imagination, edited by Dale F. Eickelman and James Piscatori. Berkeley, Los Angeles: The University of California Press, 1990.

Feener, Michael R. "South-East Asian Localisations of Islam and Participation within a 
Global Umma, c. 1500-1800." In The New Cambridge History of Islam, edited by David O. Morgan and Aanthony Reid. Cambridge, London: Cambridge University Press, 2010.

Freitag, Ulrike. "Conclusion: The Diaspora since the Age of Independence." In Hadrami Traders, Scholars, and Statesmen in the Indian Ocean, 1750-1960s, edited by Ulrike Freitag and W.G. Clarence-Smith. Leiden, New York, Köln: Brill, 1997.

Freitag, Ulrike, and Achim von Oppen. Translocality: The Study of Globalising Processes from a Southern Perspective. Leiden, Boston: Brill, 2010.

Geertz, Clifford. The Interpretation of Cultures. Chicago: Chicago University Press, 1973.

Granovetter, Mark S. "The Strength of Weak Ties." American Journal of Sociology 78, no. 6 (1973): 1360-80.

Hayden, R. M., and T. D. Walker. "Intersecting Religioscapes: A Comparative Approach to Trajectories of Change, Scale, and Competitive Sharing of Religious Spaces." Journal of the American Academy of Religion 81, no. 2 (June 1, 2013): 399-426. https://doi.org/10.1093/jaarel/1ft009.

Heer, Nicholas. “A Concise Handlist of Jawi Authors and Their Works." NELC Faculty Papers. Seattle, Washington: University of Washington, 2012. https://digital.lib.washington.edu/researchworks/handle/1773/4870.

Heigl, Andreas, and Joachim Schwarz. "Transmigration - Eine Mobilitätsstudie in Einer Herkunftsregion." ERDKUNDE 54, no. 3 (2000): 250-62. https://doi.org/10.3112/erdkunde.2000.03.06.

Houben, Vincent. "Islam and the Perception of Islam in Contemporary Indonesia." Heidelberg Ethnology, Occasional Paper, no. 3 (2015): 1-10. https://doi.org/https://doi.org/10.11588/hdethn.0.0.25362.

- "New Area Studies, Translation and Mid Range Concepts." In Area Studies at the Crossroads. Knowledge Production after the Mobility Turn, edited by Katja Mielke and Anna-Katharina Hornige. New York: Palgrave Macmillan, 2017.

Houben, Vincent, Ramon Guillermo, and Elísio Macamo. "New Area Studies as an Emerging Discipline. The Way Ahead for Southeast Asian Studies." International Quarterly for Asian Studies 51, no. 3-4 (2020): 51-64. https://doi.org/https://doi.org/10.11588/iqas.2020.3-4.13363.

Jackson, Peter A. "South East Asian Area Studies beyond Anglo-America: Geopolitical Transitions, the Neoliberal Academy and Spatialized Regimes of Knowledge." South East Asia Research 27, no. 1 (January 2, 2019): 49-73. https://doi.org/10.1080/0967828X.2019.1587930. 
Joll, Christopher M. "Local and Global Islams in Southeast Asia: Historical and Anthropological Perspectives." In Social Science and Knowledge in a Globalising World, edited by Z. Ibrahim. Petaling Jaya: PSSM/SIRDC, 2012.

Mandaville, Peter G. Transnational Muslim Politics: Reimagining the Umma. London: Routledge, 2001.

McAlister, Elizabeth. "Globalization and the Religious Production of Space." Journal for the Scientific Study of Religion 44, no. 3 (September 2005): 249-55. https://doi.org/10.1111/j.1468-5906.2005.00283.x.

Ricklefs, M.C. Mystic Synthesis in Java: A History of Islamization from the Fourteenth to the Early Nine-Teenth Centuries. Novalk: East Bridge, 2006.

Riddell, Peter G. Islam and the Malay-Indonesian World: Transmission and Responses. Honolulu: University of Hawaii Press, 2001.

. "Religious Links between Hadhramaut and the Malay-Indonesian World, C. 1850 to C. 1950." In Hadrami Traders, Scholars, and Statesmen in the Indian Ocean, 1750-1960s, edited by Ulrike Freitag and W.G. Clarence-Smith. Leiden, New York, Köln: Brill, 1997.

Seise, Claudia. Religioscapes in Muslim Indonesia: Personalities, Institutions and Practices. Berlin: Regiospectra, 2017.

- "The Transformational Power of Barokah and Silaturahmi in Muslim Indonesia." International Journal of Islam in Asia 1 (March 26, 2021): 1-20. https://doi.org/10.1163/25899996-01020001.

Sobirin, Mohamad. "Kiai Muhaimin and His Outreach Activity of Dakwah for Promoting Moderation and Preventing Conflict: Seeding Pluralism Vis-a-Vis Preaching Religion." RELIGIA 21, no. 2 (2018): 125-40. https://doi.org/10.28918/religia.v21i2.1505.

Tweed, Thomas A. Crossing and Dwelling: A Theory of Religion. Cambridge, London: Harvard University Press, 2006.

Verne, Julia. Living Translocality: Space, Culture and Economy in Contemporary Swahili Trade. Stuttgart: Franz Steiner Verlag, 2012.

Woodward, Mark R. "Indonesia, Islam, and the Prospect for Democracy." SAIS Review 21, no. 2 (2001): 29-37. https://doi.org/10.1353/sais.2001.0053.

Islam in Java: Normative Piety and Mysticism in the Sultanate of Yogyakarta. Arizona: University Arizona Press, 1989. 